УДК 811.512 .37 (Калм)

DOI: 10.18101/2305-459X-2019-4-28-33

\title{
РАННИЕ ЛЕКСИКОГРАФИЧЕСКИЕ ПАМЯТНИКИ КАК ИСТОЧНИКИ ЭТНОКУЛЬТУРНОЙ ЛЕКСИКИ КАЛМЫЦКОГО ЯЗЫКА
}

\author{
(C) Мукабенова Жанна Алексеевна \\ старший преподаватель Института калмыцкой филологии и востоковедения, \\ Калмыцкий государственный университет им. Б. Б. Городовикова \\ Россия, 358009, г. Элиста, ул. Пушкина, 11 \\ E-mail: uran@kalmsu.ru
}

\section{(ㄷ) Лиджиев Александр Борлаевич}

кандидат филологических наук, доцент кафедры русского языка как иностранного и общегуманитарных дисциплин,

Калмыцкий государственный университет им. Б. Б. Городовикова

Россия, 358009, г. Элиста, ул. Пушкина, 11

E-mail: galdma@yandex.ru

Статья посвящена описанию ранних лексикографических памятников калмыцкого языка как источников этнолингвистической информации, как средства постижения специфики культурного пространства калмыцкого этноса в целях сохранения письменного наследия. При проведении анализа в качестве эмпирической базы были использованы «ранние» двуязычные словари, составленные в XVII-XX вв.: Русскокалмыцкий словарь анонимного автора (XVIII в.); Краткий русско-калмыцкий словарь П. Смирнова (1857 г.), Калмыцко-русский словарь М. Львовского (1893 г.). Каждый из словарей представляют широкую терминологию духовной и материальной культуры народа, отражают степень включения лексических единиц в живую разговорную речь калмыцкого этноса и его субэтносов на определенном временном отрезке, а также содержат репрезентативную информацию с точки зрения диалектологических и территориальных особенностей.

Ключевые слова: калмыцкий язык, этнолингвистика, национальный корпус, «ранние» словари, диалектные особенности, лексика.

Для цитирования:

Мукабенова Ж. А., Лиджиев А. Б. Ранние лексикографические памятники как источники этнокультурной лексики калмыцкого языка // Вестник Бурятского государственного университета. Язык. Литература. Культура. 2019. Вып. 4. C. 28-33.

В настоящее время в области теоретической и практической лексикографии, появляются новые подходы и методы, связанные с разработкой, созданием и исследованием лексикографических памятников. Изучение лексического фонда языка, который бесспорно является феноменом культуры, неразрывно связано с культурно-историческим своеобразием и спецификой того или иного народа. Лингвоантропоцентрический подход, который предполагает интеграцию историко-этнографических, социо-культурологических, географических и собственно лингвистических данных, дает возможность выявить и проанализировать специфику языковой картины мира народа. 
Ж. А. Мукабенова, А. Б. Лиджиев. Ранние лексикографические памятники как источники этнокультурной лексики калмыцкого языка

Одной из актуальной задачей для этнолингвистики является изучение словарного состава «ранних» лексикографических памятников, которые могут служить надежными источниками этнолингвистической информации отдельного этноса, а также как средства постижения лингвокультуры народа.

Целью нашей работы является обзор ранних двуязычных словарей калмыцкого языка для использования их в качестве источников этнолингвистического исследования.

Первые сведения о калмыцком языке относятся к началу XVII века, в этот же период были сделаны первые записи калмыцких слов. B XVIII-XIX вв. благодаря православным миссионерам и путешественникам были подготовлены первые грамматики и лексикографические работы. К одним из самых ранних известных лексикографических источников калмыцкого языка относятся следующие работы:

1. Русско-калмыцкий словарь анонимного автора (XVIII в.) [5, 104 с.];

2. Смирнов П. Краткий русско-калмыцкий словарь (1857 г.) [Смирнов, 1857, $127 \mathrm{c.}$;

3. Львовский М. Калмыцко-русский словарь (1893г.) [Львовский, 1893, 127 c.].

Рассмотрим вышеуказанные лексикографические памятники с точки зрения их репрезентативности как источника этнолингвистической информации.

Одним из самых «ранних» словарей калмыцкого языка является «Русскокалмыцкий словарь анонимного автора» и датируется XVIII в. Как известно данный лексикографический источник под названием «Словарь языка калмыцкого» (Эрмитажное собр. № 221) поступил в рукописный отдел Российской национальной библиотеки (РНБ) из собрания Екатерины II. Это переплетенная рукопись объемом 104 страницы. Его копия, состоящая из трех частей (страницы 1-39; 40-80; 81-104), хранится в Научной библиотеке им. П. Э. Алексеевой КИГИ РАН» [Сост. В. В. Куканова, Н. М. Мулаева, с. 6]. Словарь состоит из 104 страниц и включает в себя 2988 словарных входов, расположенных в алфавитном порядке. Структура словарной статьи содержит следующие элементы:

1) слова на русском языке;

2) транскрипции (местами транслитерация) калмыцкого эквивалента на кириллице со знаками ударениями акут (') и грависа (');

3) слова на «тодо бичиг» расположены в третьем столбце в горизонтальной записи. Изданный с помощью литографии рукописный памятник содержит ценный этнолингвистический материал, так как отражают лексические единицы не только калмыцкого языка XVIII в., но устаревшую лексику русского языка того периода, причем частично диалектного характера. В данном лексикографическом памятнике, несмотря на сравнительно небольшой формат, содержатся практически все пласты лексики материальной и духовной культуры калмыков. Кроме того, в памятнике представлены элементы, отражающие рыболовную лексику, что характерно, в большей степени, для калмыков, проживавших близ Волги и Каспийского моря.

- лексика родства: прадед ‘elenceq’; дед ‘ӧbökö’; бабушка (по отиу) ‘emege eke'; omeu 'ecege'. 
- фитонимическая лексика: овес ‘arbay’; польнь ‘šaralǰin’, pena ‘cūnaq’; яблоня 'almani išì'; opex ‘šidliq'; верба 'buryusun'.

- зоонимическая лексика: лев 'arsalay'; медведь 'ауй’; волк 'сопо'; лисица 'arāta'; заяи 'tulay'; судак 'botōxoy'; карась 'balaq'; лещ 'cūba', ящерииа 'gürbülge'; змея 'тоүоу'; черепаха 'yastu mekeley', лягушка 'mekelē'; жаба 'bаха', лошадь 'morin'; жеребеи 'ајігүa'; жеребенок 'unuүan', петух 'ere takā'; курица 'takā'; индейка 'nemeš takā'.

- лексика, связанная с бытом и занятиями: дом 'ger'; кафтан 'örmögö’; $p$ -

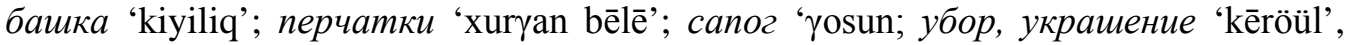
похлебка 'sölün'; масло 'tosun'; сито 'elgeq'; ступа 'ūr'; бадья 'utuxur', наперсток 'xurubči'; игла 'zöün', вериа 'burā gölmö'; невод 'yeke šöügöül’; сеть

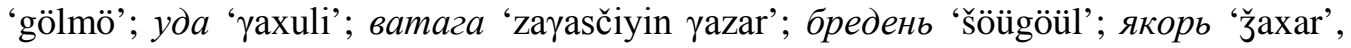
кольчуга 'kö'; меч, сабля 'üldü', лекарь 'етс̌i'; лекарство 'ет'; оспа 'сесеq'; лихорадка 'bezege', стрелеи 'xarbāči'; латник 'xuyaq kümün'; порох 'dari', свинеи

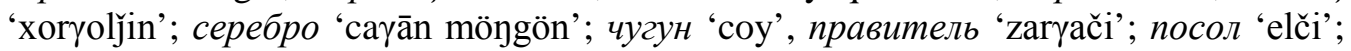
переводчик, толмач 'kölböröülēči'.

- соматическая лексика: вежади, реснищьы 'sormison'; лоб 'maฤnay'; нос 'xamur'.

В целом лексический состав памятника отражает определенный этап развития калмыцкого языка на рубеже XVIII - начала XIX вв., характеризующийся закономерной близостью с живой народной речью.

«Краткий русско-калмыцкий словарь» был создан священникоммиссионером, членом Петровского общества по изучению Астраханской губернии, учителем калмыцкого языка Парменом Смирновым и издан в 1856 г. в типографии Казанского университета [Толстой, с. 3]. Этот источник содержит 3184 словарных статей, которые расположены по двум колонкам на 118 страницах, а его структура состоит из следующих элементов:

1) слово на русском языке (в орфографии до 1917 г.);

2) перевод на калмыцком языке, написанный на «тодо бичиг» или дефиниции безэквивалентной лексики.

Орфографическая передача калмыцких слов на «ясном письме» имеет многочисленные неточности, что конечно не умаляет значение данного лексикографического памятника. Описание реалий материальной и духовной культуры, фиксация языковых особенностей лексики предполагает полное погружение лексикографа в региональную лингвокультуру. По своему лексическому составу словарь Пармена Смирнова уникален и свидетельствует об обширных и глубоких знаниях калмыцкой культурой, обычаев и традиций. В словаре достаточно широко представлена профессионально-бытовая, этнографическая, духовнокультурная лексика, отражающая различные стороны хозяйственной и духовной деятельность калмыцкого народа. Миссионерской деятельностью среди калмыков определяется факт включения в словарь христианских религиозных терминов и их эквивалентов на калмыцком языке, например ангел angel «ангел».

Основные тематические группы слов в словаре следующие:

- термины родства: батюшка аbа «аба»; дядя по отиу аbаүu «абаһу»; брат старший аха «аха»; внук ас̌і «ачи». 
Ж. А. Мукабенова, А. Б. Лиджиев. Ранние лексикографические памятники как источники этнокультурной лексики калмыцкого языка

- фитонимическая лексика: ир (растение) andis «андис»; арженик (растение из семейства злаков, похожее на рожь) ariu ӧbüsün «ариу өбүсүн»; мята (растение) badaraški «бадарашки».

- зоонимическая лексика: лисица ünegen «үнэгэн»; барс bars «барс», мерин aqta «агта»; жеребеи аjirya «ажирһа»; верблюжонок botoxon «ботохон», куропатка (птииа) уotun «йотун»; воробей boqšurүoy «богшурһой»; муха bataүana «батаһана»; комар (насекомое) bökӥnе «бөкүүнэ».

- географическая лексика: остров заселенный dobon «добон; Волга Ijil «Ижил»; долина kӧdō «көдөө».

- слова, обозначающие явления природы: морозеи zökün «зөкүүн»; гроза yike salkitay xura «йикэ салкитай хура»; мороз, стужа kiyitün «кийитүн».

- бытовая лексика: sūri yazar «нутуг; суури haзар»; крыша дома dēbür «дээбүүр»; кошма išige «ишигэ», дудка, флейта biškiür «бишкиур»; балалайка dombor «домбор»; мешок из коровьей кожи, в который вливают жидкость arxad «архад».

- медицинские термины: лекарь, врач етс̌і «эмчи»; жаба (болезнь) baqba gem «багба гэм».

- военная, рыболовная и охотничья лексика: враг, неприятель dayisun «дайисун»; крюк, снасть рыболовная dügе̄ «дүгээ»; лук, дуга, перетянутая тетивой numun «нумун»; дробь свинщовая (горох) burcuq; burčig «бурцуг; бурчиг».

- термины, обозначающие сословия, титулы, профессии: государь, сударь aldar «алдар»; князь noyon «нойон»; архиерей šajin lama, arkirey «шажин лама, аркирэй»; купеи хudaldāči «худалдаачи»; кузнеи darxас̌i «дархачи»; наемник yalči «йалчи».

- религиозная лексика: бог, божество burxan «бурхан»; освятить šijitey bolyoxu «шижитэй болһоху»; вода, подслащенная сахаром и подкраменная шафраном aršān «аршаан».

Интересным является тот факт, что некоторые лексические элементы уже не употребляются или изменили свое значение. Например, в словаре слово библиотека передается в виде словосочетания suduriyin ger, которое состоит из слов судр «сутра (книга в виде отдельных длинных несброшюрованных листов буддийского содержания)» и гер «дом, жилище». В современном калмыцком языке «библиотека» трактуется как «номин саң», где ном «книга, учение», а саң «фонд».

Рукопись П. Смирнова содержит определенное количество лексики, связанной с рыболовной деятельностью, в том числе названия рыб, рыболовных снастей и средств водного транспорта. Это говорит о том, что в основе словаря лежит торгутский диалект калмыков, кочевавших вблизи Астрахани и Волги.

В 1893 г. иеромонахом Мефодием Львовским (в миру Николай Васильевич Львовский) был написан и опубликован литографическим способом «Калмыцкорусский словарь» [Львовский, 127 с.]. Будучи студентом Казанской семинарии и знатоком калмыцкого и монгольского языков, Мифодий был направлен в Кавказскую епархию Ставропольской губернии, где проводил широкую миссионерскую работу среди калмыков Большедербетовского улуса. Словарь, подготов- 
ленный Мифодием Львовским содержит 8749 слов. Структура включает следующие элементы:

1) слово на «тодо бичиг» расположенное вертикально;

2) транслитерация на кириллице;

3) перевод на русский язык или дефиниции безэквивалентной лексики. Слова расположены на каждой странице в три столбца. Как и вышеуказанные лексикографические памятники, данный словарь содержит лексику, касающуюся самых разнообразных сторон деятельности калмыков-кочевников, природных явлений, ландшафта и т. д.: күмүске «брови»; көл «нога, голень; ноги»; көл күндү «беременность, беременная»; килиниэту хорхой «скорпион, рак»; килима загасун «осетр»; көкө байбанг «синий скорпион»; көгөлчжиргене «голубь», көдөри «кабарга, выхухоль»; көдөрийн заар «мускус»; күүги «уда, крючок рыболовный»; могой «змея»; могой загасун «угорь (рыба)»; күлген «верховое или вьючное животное; метаф.: всякое средство, сообщение; путь, средство, способ»; күлкү «закладывать, запрягать, седлать», күлмүк «мох»; бөс «бумажная ткань, тонкое полотно», бүс «пояс, кушак, портупея»; бөөсүн «вошь, насекомое»; бүсөлөөр «широкий пояс, кушак, опояска», бүүрге «седельная луна». В словаре М. Львовского отражена диалектная лексика калмыков, проживавших в Большедербетовском улусе Ставропольской губернии, на основе которого и был создан лексикографический памятник.

Калмыцко-русские и русско-калмыцкие словари, несомненно, представляют большой интерес для изучения калмыцкого языка в диахронии. Анализ показывает, что ранние словари тесно связанны с устной фольклорной традицией, а также отражают степень включения лексических единиц живой разговорной речи калмыцкого этноса и его субэтносов. Как правило, создатели этих словарей сами были собирателями фольклора, первыми этнографами, описавшими быт и культуру калмыцкого народа. Более того каждый словарь является репрезентацией речи определенной территории кочевий калмыцкого народа, по этой причине они содержат яркие черты диалектной речи определенного исторического периода. Таким образом, лексика, зафиксированная в ранних словарях, представляет собой ценную информацию для изучения истории калмыцкой языка, изменений словарного состава национального языка, для более точной характеристики языковой картины мира, как отражение взаимодействия языков и культур в регионе на определенном историческом отрезке, а также как средства постижения культурного пространства калмыцкого этноса.

\section{Литература}

1. Копыленко М. М. Основы этнолингвистики. Алма-Ата: Евразия. 1995. 180 с.

2. Львовский М. Калмыцко-русский словарь. 1893.127 с.

3. Мулаева Н. М. Русско-калмыцкий словарь Пармена Смирнова как источник изучения лексики калмыцкого языка // Участие калмыков в укреплении российской государственности: материалы рег. науч.-практ. конф., посвящ. 1150-летию российской государственности и Году российской истории (Элиста, 29 ноября 2012 г.). Элиста: Издво КИГИ РАН, 2012. С. 187-191.

4. Очирова Н. Ч. «Ранние» словари калмыцкого языка и современные информационные технологии // Участие калмыков в укреплении российской государственности: мат-лы рег. науч.-практ. конф., посвящ. 1150-летию Российской государственности и Году российской истории (Элиста, 29 ноября 2012 г.). Элиста: Изд-во КИГИ 
Ж. А. Мукабенова, А. Б. Лиджиев. Ранние лексикографические памятники как источники этнокультурной лексики калмыцкого языка

PAH, 2012. C. 183-86.

5. Русско-калмыцкий словарь анонимного автора (XVIII в.). 104 с.

6. Русско-калмыцкий словарь анонимного автора, XVIII в.: / транслит.

Н. М. Мулаева, Н. Ч. Очирова; сост. В. В. Куканова, Н. М. Мулаева; отв. ред. Е. В. Бембеев, В. В. Куканова [Электронное издание]. Элиста: Изд-во КИГИ РАН, 2014. $570 \mathrm{c}$.

7. Смирнов П. А. Краткий русско-калмыцкий словарь (в пер.). Казань: Тип. Казанского ун-та, 1857. $127 \mathrm{c.}$

8. Толстой Н. И. Язык и народная культура. Очерки по славянской мифологии и этнолингвистике. М.: Индрик, 1995. 512 с.

9. Толстой Н. И., Толстая С. М. Славянская этнолингвистика: вопросы теории: материалы ко Второму всерос. совещ. славистов 5-6 ноября 2013 г. М.: Институт славяноведения РАН, 2013. 240 с.

Статья подготовлена при финансовой поддержке РФФИ в рамках научного проекта №19-012-00531 «Лексика материальной культуры калмыцкого языка: опыт этнолингвистического исследования».

\section{EARLY LEXICOGRAPHIC MONUMENTS AS SOURCES OF ETHNO-CULTURAL LEXICS OF THE KALMYK LANGUAGE}

\section{(C) Zhanna A. Mukabenova}

Senior Lecturer, Institute of Kalmyk Philology and Oriental Studies

Kalmyk State University named after B. B. Gorodovikova

11, Pushkina Str., Elista, 358009, Russia

\section{(C) Alexander B. Lidzhiev}

$\mathrm{Ph}$. D of Philological science, Associate Professor of the Department of the Russian Language as a Foreign and Humanitarian Disciplines

Kalmyk State University B. B. Gorodovikova

11, Pushkina Str., Elista, 358009, Russia

The article is devoted to the description of the early lexicographic monuments of the Kalmyk language as sources of ethnolinguistic information, as a means of understanding the specifics of the cultural space of the Kalmyk ethnic group in order to preserve the written heritage. During the analysis, the "early" bilingual dictionaries compiled in the 17th - 20th centuries were used as an empirical base: Russian-Kalmyk dictionary of an anonymous author (18th century); A brief Russian-Kalmyk word-varic of P. Smirnov (1857), KalmykRussian dictionary of M. Lvovsky (1893). Each of the dictionaries represents a broad terminology of the spiritual and material culture of the people, reflects the degree to which lexical units are included in the living spoken language of the Kalmyk ethnic group and its sub-ethnic groups at a certain time interval, and also contain representative information from the point of view of dialectological and territorial features.

Keywords: Kalmyk language, ethnolinguistics, national corpus, "early” dictionaries, dialectal features, vocabulary. 